ARXIU D'ETNOGRAFIA DE CATALUNYA, N. 3, 1984

\title{
GUIA GENERAL PER A L'ESTUDI DE L'ETNICITAT I DELS PROCESSOS MIGRATORIS *
}

\author{
Joan A. Pujadas \\ Departament d'Antropologia Cultural de Tarragona. \\ Institut Català d'Antropologia
}

- Vull agrair a tots els membres del Seminari d'Etnicitat de l'Institut Català d'Antropologia els Comentaris i critiques que han fet d'una part de la guia que presentem, durant el període 1981-1984, en què hem treballat junts el tema de l'etnicitat. Dolors Comas ha revisat tot el text sencer $\mathrm{i} \mathrm{m}$ 'ha fet comentaris inestimables als borradors d'aquest text. La Fundació Jaume Bofill va finançar un projecte de recerca l'any 1983. durant el qual es varen redactar els annexos primer i cinquè. A tots, doncs, gràcies. 
Aquesta guia de treball vol ésser una primera versió formalitzada d'alguns dels materials metodològics aplegats durant els darrers anys, que hem dedicat a l'estudi de la identitat ètnica, les migracions i la qüestió nacional a Catalunya. No pretenem, per ara, exhaustivitat i som plenament conscients de les mancances de tot tipus que encara són presents en aquest projecte.

La característica principal d'aquesta guia és la pretensió d'obertura metodològica, que reconeix els estudis antropologics sobre etnicitat solament com una de les moltes tradicions possibles, dins el nostre camp de treball. La nostra crítica fonamental a aquesta tradició rau en el caràcter simplificador i mistificador d'una anàlisi situacionalista de nivell micro, que posseeix un potencial explicatiu molt baix.

El bagatge conceptual i metodològic amb què l'antropòleg s'enfronta amb aquesta problemàtica resulta molt escàs $\mathrm{i}$ pot abocar fàcilment a una actitud reduccionista. L'auto-reclusió dels antropòlegs dins l'àmbit de l'anàlisi simbòlica, del treball de comunitat i de les transformacions "culturals" dels contingents tribals en l'àmbit urbà, adobades d'essencialisme i sincronisme, impedeixen una aproximació globalitzadora i d'una major força explicativa. D'altra banda, hi ha per part de tota l'Antropologia funcionalista i simbolista, la convicció que existeix una relació causal i directa entre el fet d'ésser culturalment diferent $\mathrm{i}$ el fet de la identitat ètnica.

Evidentment, el nostre propòsit en redactar $\mathrm{i}$ ordenar aquests materials per a l'estudi de l'etnicitat $\mathrm{i}$ els processos migratoris, no és negar la hipòtesi general segons la qual la consciència de la identitat ètnica es basa en el caràcter específic i divers del repertori cultural i simbòlic del propi grup. Ara bé, considerem necessari centrar la investigació dels processos ètnics aprofundint en les causes econòmiques i polítiques que activen els contrastos $\mathrm{i}$ les lluites ètniques. Perquè no hi ha dubte que si abandonem una anàlisi estrictament sincronista, la història ens demostra com dos grups ètnics, segons les circumstàncies de cada moment històric, poden fer un esforç en cercar tot allò que posseeixen de comú o bé tot allò que tenen de diferent. Grups ètnics nacionals tan diferenciats $i$ amb una llista tan llarga d'enfrontaments, com britànics i francesos, varen unir les seves forces i cercar la unitat durant la Segona Guerra Mundial perquè tenien uns forts interessos comuns. 
Exemples com l'anterior, i molts d'altres, ens demostren que no hi ha res d'estable i d'immutable en la configuració de la identitat ètnica d'un grup humà. Podríem arribar a l'afirmació que la identitat ètnica es basa molt més en la mobilització coHectiva en què es manifesta allò que no es vol ser, que no pas al voltant de la definició del que realment es vol ser. Dit en altres paraules, la mobilització ètnica requereix una situació de negació del propi ésser de grup, un contrast amb un altre grup ètnic, el qual nega d'alguna forma l'existència del propi grup. Si acceptem això, queda clar que la definició de l'especificitat i la selecció dels símbols dominants i mobilitzadors són el fruit d'una circumstància històrica concreta i que ha d'ésser explicada també històricament.

El caràcter històric $\mathrm{i}$ específic de les confrontacions ètniques fa inviable un marc metodologic holístic que pugui servir tant per a l'estudi de la relació entre els grups ètnics de l'Estat de Swat, al Pakistà, com de les relacions entre canacs i caldotxes a Nova Caledònia, com de les relacions ètniques entre paios i gitanos a la nostra mateixa societat. El nostre marc metodològic pretén, simplement, servir de base per al treball a Catalunya i a les altres nacionalitats de l'Estat Espanyol i, potser per extensió, per a l'anàlisi de la situació ètnica d’aquells països més pròxims al nostre.

La guia, com a tal, es compon del material següent:

(1) Guia de treball per a l'estudi d'històries de vida individuals i de grups familiars (annex $n .^{\circ} 1$ ).

- Model de carta de parentiu (annex . $^{\circ} 2$ )

- Model-fitxa per a la construcció de xarxes socials (annex n. ${ }^{\circ}$ ).

(2) Guia de treball per a l'estudi institucional. Fa referència a institucions polítiques, educatives, religioses, econòmiques i culturals. Inclou una guia de treball per a l'estudi d'associacions (annex $n .^{\circ} 4$ ).

(3) Enquesta sobre immigració, inserció social i actituds ètniques. Inclou una introducció $\mathrm{i}$ el text de l'enquesta (annex $\mathrm{n} .^{\circ} 5$ ).

(1) GUIA DE TREBALL PER A L'ESTUdi D'HISTÒRIA DE VIDA INDIVIDUALS I DE GRUPS FAMILIARS (cfr. annex n. 1).

Es compon d'una part estrictament biogràfica, pensada essencialment per a recollir les vivències de la població immigrada o emigrada, però que és també perfectament vàlida per a l'estudi d'individus i grups familiars no migrants. L'objectiu d'aquesta part és donar un marc històric personal que introdueix els altres apartats, $i$, alhora, unes claus a l'investigador per a poder interpretar les motivacions $\mathrm{i}$ actituds ètniques dels individus observats.

Tot un altre bloc d'apartats de la guia té com a objectiu la caracterització de l'entorn de cada grup domèstic: l'àmbit familiar més ampli, l'àmbit de les relacions socials, l'àmbit laboral i l'àmbit comunitari. Es tracta de veure si existeixen correlacions significatives entre el tipus i la intensitat de relacions familiars, d'una banda, i el grau d'integració sòcio-cultural i econòmico-laboral dins el país on es resideix. Aquest aspecte es mostra més significatiu encara en el cas de les famílies recentment immigrades, especialment si es tracta d'una immigració de fora de Catalunya, o de fora del país estudiat en cada cas.

Per a formalitzar el grau i la intensitat d'aquestes relacions familiars disposem del model-fitxa que ens permetrà construir la carta de parentiu corresponent a cada grup domèstic estudiat ( $\mathrm{cfr}$. annex $\mathrm{n} .^{\circ} 2$ ). Es tracta, en primer lloc, partint del nostre informant o ego, de fer un inventari de tots els familiars que aquest coneix directament, sense ajut d'un altre membre del grup domèstic, tot indicant a l'imprès corresponent les dades referents a cada familiar que recordi en aquell moment. Cal remarcar que no es tracta de tenir una carta de parentiu molt completa, sinó de saber exactament quines són les relacions reals de cada individu. Per això resulta tan significativa la informació que es té com la que no es recorda.

Un cop fet l'inventari d'individus, i seguint les normes convencionals emprades en la construcció dels diagrames de parentiu, es tracta de representar la carta de parentiu, segons l'exemple del model reduït que s'inclou en l'annex $n .^{\circ} 2$

Els apartats dedicats a l'estudi de l'àmbit laboral i comunitari són especialment significatius per a perfilar l'entorn social més ampli, com també l'apartat de relacions socials és significatiu per a detectar la integració i les actituds culturals $\mathrm{i}$ lingüistiques de la població analitzada. L'annex $\mathrm{n} .^{\circ} 3$ ens permet emprar una tècnica sociomètrica, que possibilita d'alguna forma, mesurar el grau, la intensitat i el caire de les relacions globals que l'individu i el grup domèstic estableixen amb el seu entorn més immediat. El que es tracta de fixar són els criteris o els àmbits dominants en el procés de reclutament d'aquestes relacions socials.

Finalment, en el darrer apartat, dedicat explícitament a la identitat cultural i a les actituds ètniques, es tracta de veure el grau de coherència existent entre el comportament estudiat $i$ observat $i$ el tipus de racionalitzacions i elaboracions mentals que els individus fan per a representar-se ells mateixos dins les diferents opcions disponibles; en definitiva, de veure si les 
pròpies actituds són el resultat d'unes «condicions» objectives de tipus material i social, d'una banda, i, d'altra, comprovar el grau de consciència quant al valor d'aquestes actituds.

\section{(2) L'estudi institucional.}

Aquesta divisió de la guia de treball pretén incloure totes les dimensions institucionals $\mathrm{i}$, per tant, formals que emmarquen $\mathrm{i}$ condicionen els comportaments individuals $\mathrm{i}$ grupals, tal com els hem estudiat a l'apartat anterior. Es distingeixen, essencialment, cinc tipus d'institucions:

- Institucions polítiques.

- Institucions educatives.

- Institucions religioses i para-religioses.

- Institucions econòmiques.

- Institucions reivindicatives i/o culturals de caire voluntari.

Resulta molt difícil d'assajar l'elaboració d'una llista tancada d'aquelles institucions que estan implicades en els processos ètnics; de fet, totes ho estan. Ara bé, amb ànim de clarificació i de jerarquització és necessari partir d'una concreció dels àmbits institucionals respecte als quals hem d'ordenar $\mathrm{i}$ analitzar tota la informació que resulta de l'anàlisi individual i familiar del comportament $\mathrm{i}$ de les actituds ètniques.

\subsection{Les institucions politiques.}

Sota aquest epígraf ens volem referir a totes les institucions administratives, judicials i legislatives d'àmbit estatal i autonòmic, provincial i local, no compreses en altres apartats. Més que les institucions en elles mateixes, que representen una nebulosa plena d'opacitat per a la majoria dels ciutadans, ens volem referir a aquelles dimensions de la vida política que són més públiques $\mathrm{i}$ que tenen una incidència $\mathrm{i}$ un grau de transparència més gran a nivell de carrer.

Un dels aspectes més interessants i amb més trascendència pública de l'activitat de govern a qualsevol país, és la politica d'impostos, relacionada amb la puja del nivell de vida i el nivell salarial. Resulta curiós de veure com aquest tema, en què els protagonistes són les forces «econòmiques» i «socials», presumiblement arbitrades pel govern de torn, fàcilment pot ésser manipulat d'una manera convenient per a convertir la lluita de classe en una qüiestió de països rics i països pobres, això és, en una qüestió de greuges comparatius entre les diferents comunitats de l'Estat. Aquesta manipulació, que porta darrera tot un passat $\mathrm{i}$ tota una pràctica lerrouxista, resulta extraordinàriament interessant d'ésser estudiada des del punt de vista d'actituds $\mathrm{i}$ de conceptes per part d'informants de diferents origens nacionals dins l'Estat Espanyol. Aquest tema de les confrontacions ètniques com a transformació de les confrontacions de classe, a més d'ésser teòricament molt important, representa una de les qüestions més omnipresents per a l'anàlisi de les relacions sòcio-polítiques a l'Estat Espanyol. Ho comprovarem especialment quan abordem la problemàtica de les mobilitzacions ètniques $i$, sobretot, quan estudiem dins el comportament electoral popular la justificació del vot a partir de la disjuntiva entre la preponderància de la solidaritat de classe o la solidaritat ètnica. Noti's bé, que per la classe dirigent, els «seus» interessos són presentats sempre com els interessos de «tota» una nació, de tot un poble.

Un tema important d'estudiar és el del valor simbòlic unitarista d'institucions com la monarquia, la bandera nacional $\mathrm{i}$ les forces armades, que encarnen dins l'estat constitucional els tres suports bàsics de la idea de nació espanyola. Parallelament, cal veure la importància simbòlica que es dóna en algunes comunitats autònomes a la creació de cossos armats propis. Destaca també el culte generalitzat que es dóna a les banderes autonòmiques, locals, etz., especialment en aquelles comunitats amb un passat històric molt carregat, o en aquelles altres amb un present més clarament diferenciat o conflictiu en la seva integració al conjunt de l'Estat (recordi's la «guerra de les banderes» de fa uns mesos al País Basc).

Un dels fenòmens més destacats a l'Espanya dels darrers deu anys és la incorporació de la societat civil a la vida política mitjançant la reinstauració de les institucions d'un Estat monàrquic parlamentari. La consecució de la democràcia anava associada en alguns dels territoris, com Catalunya, País Basc, Andalusia o Galícia, a la reivindicació d'Autonomia política. Cal veure, doncs, com l'eufòria per la democràcia era també una eufòria per l'Autonomia $\mathrm{i}$ les llibertats nacionals. També el desencant per una va arrossegar desencís per l'altra. Es extraordinàriament important d'estudiar la identificació $\mathrm{i}$ les crítiques que els ciutadans de diferents orígens ètnics fan de tot aquest procés. Especialment es trata d'incidir en l'estudi dels estereotips nacionalistes, sobre els «costos» de l'autonomia i, també, sobre la quiestió de si es pot parlar d'autonomies de "primera» i de «segona».

Directament associat amb el tema anterior, és el de centrar l'atenció en els problemes i les actituds de la gent sobre l'evolució política de les 
administracions autonòmiques; és a dir, veure què ha canviat en la vida pública d'una nacionalitat després de la constitució dels governs autonòmics i de l'inici dels traspassos de competències. L'acostament de l'administració i l'administrat, ¿ha millorat els serveis? Fer una anàlisi paraHlela referida als governs municipals i a la participació ciutadana en la vida pública local.

D'altra banda, cal veure la incidència que la vida parlamentària i la seva repercussió als mitjans de comunicació de masses té sobre els ciutadans, i el grau d'informació, participació i/o mobilització que hom experimenta sobre els afers públics. Aquest tipus d'anàlisi es pot complementar amb una altra del nivell de participació, militància $\mathrm{i}$ resposta electoral dels diferents partits dins un àrea determinada, d'àmbit local o comarcal.

Finalment, hi ha una qüestió especialment interessant des de la perspectiva de l'etnicitat, en què els poders públics $\mathrm{i}$, molt especialment l'exèrcit $\mathrm{i}$ els diplomàtics, són els protagonistes. Em refereixo als episodis sobre la «soberanía nacional». Temes d'estat eterns com el de Gibraltar, Ceuta i Melilla o l'espanyolitat de les Illes Canàries han ocupat, ocupen, i ocuparan sens dubte, moltes pàgines als diaris, $\mathrm{i}$ sobre els quals hom pensa que hi ha més unanimitat; és qüestió de patriotisme. Aquí recuperem un argument que ja hem citat més amunt: la identitat com a resultat del contrast. En els casos damunt dits, el que està clar és que Gibraltar no és britànic, i que Ceuta, Melilla i Canàries no són del Marroc. Aquests contenciosos no impedeixen, però, que les formulacions de política diplomàtica assenyalin sempre la vocació d'Espanya vers el Mogreb, tot referint-se a «les tradicionals relacions d'amistat i cooperacióm. Un altre registre associat també a la qüestió de l'ésser d'Espanya $\mathrm{i}$ de la seva definició geo-estratègica és la seva vinculació a Europa i el mal dissimulat complex d'inferioritat. En darrer terme, vull referir-me, encara, al patriotisme d'Estat, associat a un esplendorós passat colonialista, $\mathrm{i}$ que ha deixat la seva empremta ideològica en el nacionalisme d'estat actual (de dreta $\mathrm{i}$ esquerra): la «hispanidad", tant de moda avui en dia amb els preparatius de celebració del cinquè centenari del «Descubrimiento".

\subsection{Les institucions educatives.}

L'aparell educatiu espanyol conserva un cert equilibri entre ensenyament públic i privat, amb un predomini d'aquell a les zones rurals i els barris obrers, i una clara extensió d'aquest a les zones urbanes de classes mitjanes $\mathrm{i}$ altres. Al dessota d'aquesta primera divisió n'apareixen dues altres: ensenyament públic estatal $\mathrm{i}$ autonòmic, $\mathrm{i}$ ensenyament privat religiós $\mathrm{i}$ no reli- giós. Fins fa poc, l'ensenyament públic era exclusivament de competència estatal, mentre que ara, especialment als nivells extrems de l'ensenyament pre-escolar i a la primera etapa d'ensenyament primari, com també a l'ensenyament universitari, s'experimenta, en moltes comunitats autònomes, un procés d'arrelament a la pròpia realitat nacional i lingüística bastant important, fins i tot en una situació en què els traspassos de competències de l'Estat a les comunitats autònomes són encara molt incomplets. Aquest procés de «catalanització», «euskaldunització», etc., de l'ensenyament, és vist, però, per molts immigrants en aquestes comunitats autònomes com una agressió al seu dret a rebre un ensenyament en la seva pròpia llengua: conflicte d'interessos, conflicte d'integració social, conflicte de polítiques d'ensenyament que cal estudiar, ja que representen qüestions essencials per a la convivència cívica.

Pel que fa a l'ensenyament privat, la seva oferta és molt més selectiva, i s'acomoda millor als interessos de les diferents capes socials a les quals s'adreça. És interessant estudiar el nou plantejament de l'ensenyança dels collegis religiosos en el procés polític d'aquests darrers anys, tot fent comparances entre diferents comunitats autònomes.

En aquest apartat és especialment interessant veure el tema de les polítiques educatives $\mathrm{i}$ dels actuals debats sobre autonomia universitària, sobre el dret a l'ensenyament $\mathrm{i}$, sobretot, en relació al concepte de llibertat d'ensenyament. Aquests debats es donen i tenen una presència molt contrastada a nivell de carrer, segons es tracti d'una o altra comunitat autònoma.

Un últim aspecte a tractar, potser impròpiament dins aquest capítol, és el que fa referència a institucions d'àmplia projecció cultural $\mathrm{i}$ educativa, com són les «acadèmies de la llengua»: Real Academia de la Lengua Española, Institut d'Estudis Catalans, Real Academia de la Lengua Vasca, etc. El seu paper simbòlic és notable i evident. Les connotacions entre la primera i les altres dues és notòria. La primera és un reflex d'aquell passat imperial esplendorós; $\mathrm{i}$ la seva estructura, que inclou les acadèmies dels altres Estats hispano-parlants, li dóna un paper protagonista en el manteniment de la idea d'hispanitat. Les altres dues institucions han estat més aviat precàries, $i$ han passat la major part de la seva història en la clandestinitat o en una situació d'ostracisme. Ara bé, en tots els casos no hi ha dubte que representen un dels símbols més importants de la unitat i la normalització cultural i educativa del seu àmbit respectiu, a part d'ésser un instrument molt valuós en la normalització idiomàtica. 


\subsection{Les institucions religioses.}

En una terra de tan llarga tradició catòlica, tant oficial com popular, no hi ha dubte que molts dels aspectes de l'especificitat cultural estan molt directament marcats en clau religiosa o, almenys, para-religiosa. En un sentit simbòlic, $i$ també pràctic, la presència de l'església en el procés de construcció nacional d'Espanya, i de cada una de les nacions que la formen, és, i ha estat, molt important. A tall d'exemple, enumeraré alguns dels aspectes interessants d'ésser estudiats, malgrat que per a tenir una visió de conjunt d'aquest tema, cal revisar la guia de treball publicada per Joan Prat al n. 2 d'Arxiu d'Etnografia de Catalunya, amb el títol de «L'Experiència Religiosa Ordinària». Vegem-ne alguns:

- L'església i el servei social: ensenyament i sanitat (cfr. apart. 2 B de la Guia de J. Prat).

- L'església com a substrat cultural: la religió i els símbols religiosos com a centre de la vida comunitària $\mathrm{i}$, per tant, com a eix de la identitat local (cfr. apartat 3 D, E, F, ibid.).

- La sacralització de tot l'àmbit ritual i festiu, a nivell domèstic, comunitari i institucional.

- La secularització de manifestacions religioses: els aplecs (cfr. 4, ibid.).

- L'activitat missionera i la inculcació del paternalisme emvers les altres cultures no occidentals: etnisme negatiu.

- Elements d'origen religiós com a símbols supra-religiosos de clar contingut ètnico-nacional: El Pilar, Montserrat, El Rocío, Aranzazu.

- Religió com a nacionalisme: el «nacional-catolicisme» $\mathrm{i}$ altres formes de militància nacionalista.

- Alternatives a l'hegemonia del catolicisme i dificultats per arrelar-se, $\mathrm{La}$ catolicitat cultural de l'Estat Espanyol, amb independència de les taxes de participació en els cultes $i$ en la fe.

\subsection{Les institucions econòmiques.}

L'activitat econòmica, com totes les altres esferes de la vida en societat, va indissociablement unida al conjunt d'adaptacions que caracteritzen el grup humà i la seva cultura. No és estrany, doncs, que puguem trobar en aquest tipus d'activitat traces clares d'una forma d'entendre la vida, que és diferent d'una societat a una altra i, fins i tot, d'un grup social a un altre. Quan assistim a l'obstinada actitud de grups com els pasiegos, vaqueiros, gitanos i altres grups marginals, que es neguen a acceptar el mannà de la «modernització», assistim possiblement a l'últim acte d'una obra de la qual tots sabem el final abans de començar. Contràriament $a$ allò que les sofisticades $i$ subtils anàlisis de molts antropòlegs ens volen fer creure, no es tracta d'una incapacitat mental per veure els avantatges «materials» del "progrés». No és que no siguin capaços de veure-ho, és simplement que aquests avantatges són només superficials i que inclouen, per contra, la destrucció total de les bases simbòliques, culturals, ecològiques i socials de tot el grup. Resistir-se al canvi és tant com lluitar per sobreviure, és voler mantenir la identitat, negarse a ésser absorbit.

Com és fàcil de comprendre, existeixen multiplicitat de casos en què aquesta voluntat de sobreviure, de mantenir-se per sobre de la lògica assimiladora de la «normalitat», es dóna de forma quotidiana i sense l'espectacularitat dels exemples que he posat abans. Tant al camp com a la ciutat trobem representants d'oficis marginals o quasi desapareguts que conreen la seva professió, el seu ofici, convençuts de la seva utilitat social, i que es neguen a acceptar la lògica de l'assimilació.

La relació entre aquesta actitud de resistència i la voluntat de resistència com a nació, no és exclusivament metafòrica. En efecte, representa d'alguna forma un comportament enfront de la uniformització de la vida econòmica $\mathrm{i}$ cultural imposada per l'imperi de les multinacionals i els mecanismes del neo-imperialisme que generen el síndrome de la dependència tecnològica, econòmica $i$, per tant, cultural.

Davant d'aquest gran fet, trobarem respostes molt diferenciades, segons el tipus de collectiu professional que vulguem estudiar i segons el seu grau de compromís amb les diferents forces econòmiques $\mathrm{i}$ socials: des dels empresaris desenrotllistes fins als grups financers monopolistes, passant pels professionals liberals. Fins i tot dins l'àmbit sindical podem trobar notables diferències en la forma de concebre el progrés: des de l'actitud tecnocràtica i alienada de la gent d'UGT fins a les posicions més dures, però no menys tecnocràtiques, de $\mathrm{CCOO}$, o bé les d'alguns sindicats pagesos: UP (Unió de Pagesos), o SOC (Sindicato de Obreros del Campo), molt més en consonància amb el seu entorn sòcio-cultural i molt més crítiques.

Una altra dimensió interesantíssima d'estudiar és l'àmbit del cooperativisme, tant industrial (cas Mondragón) com agro-pecuari, que en molts casos és una adaptació d'antigues formes de participació comunitària que han anat caient en desús al llarg dels anys. 


\subsection{Les institucions reivindicatives o/i culturals de caire voluntari.}

Aquest apartat constitueix un veritable calaix de sastre que inclou una llista molt heterogènia d'institucions de les anomenades de caire «cultural», com també entitats de caire «reivindicatiu». Potser l'únic tret en comú és el fet que el reclutament dels seus membres és voluntari. Es tracta en general d'entitats amb objectius molt concrets, les quals, comparades amb les institucions dels apartats anteriors, posseeixen una continuitat en el temps bastant limitada. Precisament aquest factor de fugacitat temporal els confereix una significació més unívoca, davant l'ambigüitat de moltes de les institucions dels altres grups i, especialment, des del punt de vista que a nosaltres ens interessa.

Un altre aspecte a considerar en l'estudi d'aquest tipus d'institucions és el valor subtituỉdor que posseeixen en molts casos, allà on els poders públics no han creat estructures capaces de servir les necessitats dels ciutadans. Dins d'aquest apartat, les nacions i nacionalitats sense estat propi són especialment prolífiques quant a la creació d'aquest tipus d'associacions. A tall d'exemple podem citar, en el cas de Catalunya: Omnium Cultural, Rosa Sensat, el propi Institut d'Estudis Catalans, les Associacions de Veîns, els centres excursionistes, les associacions folkloristes, el moviment floralista i tants i tants centres d'estudi i ateneus. De la Renaixença ençà aquest tipus d'institucions, treballant gairebé sempre sota condicions de dictadura o d'intolerància cap a les aspiracions nacionalistes de Catalunya, han anat forjant el sentiment nacionalista dels ciutadans $\mathrm{i}$ han funcionat com a infraestructura del país, per sobre o amb independència de les activitats "ordinàries" o regulars que hom els podria suposar.

També amb valor substitutiu però de signe contrari, cal destacar el paper que en diferents moments de la història recent han jugat els «centros regionales», fortament finançats, en alguns casos, pels representants del capital oligàrquic, les castes de funcionaris i altres sectors afins. En el si del moviment obrer, el sindicalisme de començaments de segle, especialment, es va veure influenciat per les tendències lerrouxistes, disfressades d'internacionalisme i de populisme.

Actualment, les coses tendeixen a clarificar-se, i les associacions de tot tipus han abandonat, en part, la polarització política i/o nacionalista que havien assolit per mor de les circumstàncies $\mathrm{i}$ han tendit a concentrar-se en els objectius explícits que els són propis. El protagonisme passa ara, exclusivament, a aquelles entitats els objectius de les quals està més directament marcat per criteris ètnics o nacionalistes, com és el cas de les cases regionals, les associacions per a la defensa dels drets de les minories ètniques i nacionals, les associacions en defensa de la llengua $\mathrm{i}$, potser, les associacions folkloristes. Institucions amb fort contingut nacionalista, com Omnium Cultural, continuen a la bretxa, malgrat que han redefinit parcialment els objectius i les prioritats. D'altres associacions, com les de veïs, molt compromeses en el passat de la lluita per les llibertats democràtiques, han revisat també molts dels seus objectius; són molt interessants d'ésser estudiades, perquè representen un bon termòmetre dels problemes socials més significatius que afecten els ciutadans.

Finalment, vull assenyalar d'una manera explicita quelcom que està implícit en totes les pàgines anteriors: la vida associativa és el nexe d'unió entre el comportament individual i familiar, d'una banda, i l'activitat de les institucions públiques i els mecanismes de l'aparell d'Estat, de l'altra. Representa un nivell d'observació intermedi que permet a l'antropòleg enquadrar els comportaments individuals $\mathrm{i}$ els grups socials que componen una societat. Sense aquesta possibilitat d'articular el nivell més particular i el més general, no seríem capaços de veure les connexions entre els fenòmens socials globals del nostre nivell d'anàlisi etic i les actituds i idees dels subjectes concrets que nosaltres estudiem des d'una perspectiva emic. L'annex n. 4 presenta un model de guia per a l'estudi d'associacions i entitats de caire voluntari.

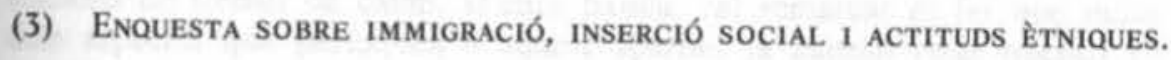

Un dels perills més grans, ja assenyalats al començament d'aquesta introducció a la guia de treball, és la tradició antropològica d'unes metodologies que enfasitzen gairebé exclusivament el nivell d'anàlisi micro. Els àmbits «naturals» del treball antropològic referits a l'etnicitat són: l'individu, el grup familiar, la comunitat $i$, com a màxim, el grup tribal. Per tot el que acabem de dir a l'apartat corresponent a les institucions, queda clar que la major part de les claus interpretatives dels fenòmens ètnics i nacionalistes són supra-comunitaris i han d'ésser emmarcats en el nivell més general de la societat que estem estudiant.

Conseqüentment, cal fer ús de tècniques extensives, en les que les relacions entre unitat d'anàlisi $\mathrm{i}$ unitat d'observació canvien de sentit $\mathrm{i}$ on les tècniques de mostreig $i$ les tècniques d'inferència són diferents dels estudis tipologistes, basats en estudis de cas. Juntament amb el treball censal, la tècnica de l'enquesta d'opinió pot ésser molt útil per a obtenir una idea de conjunt d'unitats d'anàlisi en aquelles en les quals no és possible l'observació directa, per raons de la seva escala. 
Cal, però, ésser molt prudents quant al valor dels resultats de les enquestes d'opinió. En primer lloc, les respostes i la seva veracitat no són controlables més que en part, mitjançant la reiteració solapada de preguntes. En segon lloc, la formulació de les preguntes resulta sempre inadequada per una part més o menys àmplia de la mostra d'individus, que sempre és molt diversa pel que fa a la seva educació, edat i posició social. En tercer lloc, i molt important, els resultats d'una enquesta no són mai articulables amb les altres tècniques qualitatives i tipologistes que fem servir els antropòlegs, ja que els resultats de tota enquesta no són mai ordenables per tipus de respostes, que fan referència a una totalitat àmplia, totalitat que resulta opaca per el treball d'observació directa.

Malgrat totes les reserves anteriors, la utilització d'enquestes es cada vegada més freqüent i se'n fa una eina de treball necessària per a assolir nivells d'anàlisi més amplis i globalitzadors, encara que a canvi es perdi bona part de l'especificitat del treball clàssic. Per raons d'espai i per la impossibilitat de preveure tots els casos possibles d'aplicació, no em deturaré aquí a parlar dels criteris de selecció $\mathrm{i}$ de representativitat de les mostres d'individus als que cal passar el model d'enquesta en cada cas. Pel que fa als resultats que vàrem obtenir en passar aquesta enquesta al barri de Bonavista (Tarragona), vegi's Pujadas: Immigració $i$ etnicitat: Resultats d'una enquesta al barri de Bonavista.
ANNEX $n 0^{\circ} 1$

GUIA DE TREBALL PER A L'ESTUDI D'HISTORIES DE VIDA INDIVIDUALS I DE GRUPS FAMILIARS

\section{Introducció}

Aquesta guia té en compte un doble nivell: l'individual i el familiar. Quan es recull la informació s'ha de fer sempre la distinció entre els aspectes relatius a la persona $\mathrm{i}$ els referents a la unitat familiar en el seu conjunt.

Els diferents apartats de la guia conserven un ordre lògic, que no correspon en absolut amb l'ordre en la recollida de les dades. Suggerim començar pels aspectes relatius a la història del barri o comunitat de residència on viu el grup domèstic de referència, per a derivar després cap als altres aspectes que configuren l'entrevista.

L'apartat corresponent a identitat cultural és el més problemàtic de la guia, per la complexitat teòrica, com també per les dificultats pràctiques que es deriven de realitzar una entrevista sobre un tema tan «ideològic» $i$ idiosincràtic com aquest. Recomanem, doncs, deixar-ho per al final de les sessions de treball de camp. D'altra banda, cal remarcar el fet que molts dels aspectes que pertoquen a aquest apartat, ja hauran estat tractats en apartats anteriors, per la qual cosa es fa necessari haver elaborat prèviament aquests.

Apartats de l'enquesta

(1) Dades personals.

(2) Història individual.

(3) Dades familiars.

(4) Relacions interindividuals.

(5) Àmbit laboral.

(6) Inserció al barri i/o comunitat de referència.

(7) Identitat cultural $\mathrm{i}$ actituds ètniques. 
Cal, però, ésser molt prudents quant al valor dels resultats de les enquestes d'opinió. En primer lloc, les respostes i la seva veracitat no són controlables més que en part, mitjançant la reiteració solapada de preguntes. En segon lloc, la formulació de les preguntes resulta sempre inadequada per una part més o menys àmplia de la mostra d'individus, que sempre és molt diversa pel que fa a la seva educació, edat i posició social. En tercer lloc, i molt important, els resultats d'una enquesta no són mai articulables amb les altres tècniques qualitatives i tipologistes que fem servir els antropòlegs, ja que els resultats de tota enquesta no són mai ordenables per tipus de respostes, que fan referència a una totalitat àmplia, totalitat que resulta opaca per el treball d'observació directa.

Malgrat totes les reserves anteriors, la utilització d'enquestes es cada vegada més freqüent i se'n fa una eina de treball necessària per a assolir nivells d'anàlisi més amplis i globalitzadors, encara que a canvi es perdi bona part de l'especificitat del treball clàssic. Per raons d'espai i per la impossibilitat de preveure tots els casos possibles d'aplicació, no em deturaré aquí a parlar dels criteris de selecció i de representativitat de les mostres d'individus als que cal passar el model d'enquesta en cada cas. Pel que fa als resultats que vàrem obtenir en passar aquesta enquesta al barri de Bonavista (Tarragona), vegi's Pujadas: Immigració $i$ etnicitat: Resultats d'una enquesta al barri de Bonavista.
GUIA DE TREBALL PER A L'ESTUDI D'HISTORIES DE VIDA INDIVIDUALS I DE GRUPS FAMILIARS

\section{Introduccio}

Aquesta guia té en compte un doble nivell: l'individual i el familiar. Quan es recull la informació s'ha de fer sempre la distinció entre els aspectes relatius a la persona $\mathrm{i}$ els referents a la unitat familiar ên el seu conjunt.

Els diferents apartats de la guia conserven un ordre lògic, que no correspon en absolut amb l'ordre en la recollida de les dades. Suggerim començar pels aspectes relatius a la història del barri o comunitat de residència on viu el grup domèstic de referència, per a derivar després cap als altres aspectes que configuren l'entrevista.

L'apartat corresponent a identitat cultural és el més problemàtic de la guia, per la complexitat tedrica, com també per les dificultats pràctiques que es deriven de realitzar una entrevista sobre un tema tan «ideologic» $i$ idiosincràtic com aquest. Recomanem, doncs, deixar-ho per al final de les sessions de treball de camp. D'altra banda, cal remarcar el fet que molts dels aspectes que pertoquen a aquest apartat, ja hauran estat tractats en apartats anteriors, per la qual cosa es fa necessari haver elaborat prèviament aquests.

\section{Apartats de l'enquesta}

(1) Dades personals.

(2) Història individual.

(3) Dades familiars.

(4) Relacions interindividuals.

(5) Ambit laboral.

(6) Inserció al barri i/o comunitat de referència.

(7) Identitat cultural i actituds ètniques. 


\section{DADES PERSONALS}

$\begin{array}{ll}\text { Nom } & \text { Lloc de naixement } \\ \text { Edat } & \text { Anys de residència a Catalunya } \\ \text { - Domicili } & \text {. Professió/-ons } \\ \text { - Estat civil } & \text {. Anys de residència al barri o ciutat actual }\end{array}$

(Aquestes dades és millor obtenir-les, si es pot, de forma indirecta, utilitzant els nostres coneixements directes del grup familiar estudiat o bé mitjançant els registres padronals. Cal fer una fitxa de cada persona entrevistada i afegir a les dades anteriors una caracterització «subjetivan, feta per l'entrevistador, de cada un dels membres del grup familiar, indicant el seu caràcter, les seves actituds respecte al tema de l'entrevista i respecte a l'entrevistador $\mathrm{i}$ al fet mateix que es produeixi l'entrevista.)

\section{HISTORIA INDIVIDUAL}

L'objectiu d'aquest apartat és centrar la narració de les vivències del procés migratori, per part d'aquells membres del grup domèstic que hagin viscut aquest procés. En el cas que dins d'un grup domèstic es trobin individus de dues generacions que hagin emigrat del seu lloc d'origen ja adults, cal entrevistar, com a mínim, un individu de cada generació. En tot cas, i sempre en funció de les circumstàncies de l'entrevista, es preferiran els informants de major edat, per considerar que posseeixen més vivències $i$ ofereixen més possibilitats d'establir contrastos entre la situació d'abans i de després de la migració.

2.1. Valoració i descripció de les causes que varen determinar la migrací: recollida de records sobre el lloc d'origen, infantesa, jocs, menjars, costums, relacions familiars; informació i opinions sobre altres llocs on hagin viscut; opinions sobre el caràcter de la gent dels diferents llocs: estereotips.

2.2. L'arribada al lloc de residència actual: vivències, problemes, gent coneguda (amics, parents) mitjançant els quals hom va prendre la decisió de venir...

2.3. Vinculacions amb el lloc d'origen i formes d'actualitzar els contactes amb els parents $\mathrm{i}$ amics: intensitat d'aquests contactes. Es desitja tornar?, es considera possible aquest retorn?, què pesa més, el desig de tornar al lloc d'origen o la necessitat de marxar d'un lloc que no és el propi $\mathrm{o} / \mathrm{i}$ on no s'està a gust? (Intentar esbrinar les diferències entré situació real i les representacions «ideològiques» d'aquesta realitat.)

\section{DADES FAMILIARS}

3.1. Construir l'arbre genealògic, tant per la branca matrilinial com patrilinial del grup domèstic estudiat.

3.2. Estudi de les relacions amb els parents, en els seus diferents graus i llocs de residència: estudi de xarxes familiars.

3.3. Tipus de solidaritat $i$ contraprestacions entre els parents que han emigrat a llocs pròxims: el parentiu com a forma adaptada $i$ eficaç de seguretat social.

3.4. Etapes econòmiques del grup domèstic estudiat. Situació econòmica al moment d'iniciar l'emigració. Assentament al lloc actual: possessions i propietats, nivell de despeses i llur distribució per capítols. ¿Quins són els interessos $\mathrm{i} / \mathrm{o}$ propietats que es relacionen amb el lloc d'origen?

3.5. El sistema de normes al grup domèstic, jerarquia i autoritat: sistema apeHatiu, grau de formalisme i ritualització en les relacions entre diferents generacions, jerarquia $i$ ús preferencial de l'espai domèstic, sistema de presa de decisions, llibertat individual respecte a l'autoritat familiar, rituals domèstics, control familiar de les despeses individuals, dret a opinar i formes d'expressió de la pròpia opinió, primogenitura o sexe com a criteris de jerarquia.

(Tots els diferents apartats d'aquesta secció s'han d'analitzar de forma processual tenint present l'opinió dels informants sobre el contrast de la vida de familia corresponnent al seu lloc d'origen i la realitat que ells perceben a Catalunya).

\section{RELACIONS INTERINDIVIDUALS}

4.1. Caracterització dels àmbits socials de cada un dels membres del grup domèstic: rutines quotidianes, treball, estudis, vida de relació, esplai, 
vida associativa. Intentar destacar en quina mesura les moltes o poques relacions socials de cada individu depenen del seu caràcter o actitud davant les relacions socials o bé de l'edat, el sexe, el nivell educatiu, el tipus de feina que es fa, l'origen ètnic, etc.

4.2. Construir la xarxa social dels individus del grup familiar, tenint en compte els diferents àmbits de relació possibles:

4.2.1. Àmbit familiar (cfr. apt. 3.2.).

4.2.2. Àmbit laboral (cfr. apt. 5.3.).

4.2.3. Ambit escolar (companys de classe o de collegi de la gent jove, antics companys per a la gent gran, companys d'estudis especialitzats, diferents del que es relacionen directament amb la feina).

4.2.4. Ambit veïnal (amics i coneguts d'escala, de carrer, dels bars, de les tendes, de la parròquia, de l'autobús, professionals del barri i comerciants en general).

4.2.5. Ambit associatiu (amics i companys de partit, sindicat, associació de veïns, parròquia, associacions de diferent caire, reivindicatives, o culturals, p. ex., els centres regionals o bé de tipus esportiu).

4.2.6. Altres ( $p$. ex. relacions esporàdiques amb amics d'amics, amb "paisanos», amb gent coneguda en un viatge, etc.).

\section{AMBIT PROFESSIONAL I LABORAL}

5.1. Especificació dels membres del grup familiar que treballen, tot fent una breu caracterització biogràfica de la feina o feines que es fan $\mathrm{i} / \mathrm{o}$ s'han fet anteriorment.

5.2. Breu anàlisi sobre el sistema de representacions relacionat amb el treball: si es considera una obligació o un do o bé un càstig; si agrada la pròpia feina, i si se la classifica com un tipus determinat dins una tipologia (indicar, en el seu cas, quins són els eixos d'aquesta classificació i quines les professions de més i menys prestigi); si pensa que ésser treballador és o no una virtut; si es tenen uns estereotips ètnics relacionats amb el treball.

5.3. L'àmbit laboral com a generador de relacions socials, especificar quines persones d'entre els companys de treball tenen amb el/els membre/-s del grup domèstic relacions socials extra-laborals.
5.4. Tipus de feina que es realitza, tipus d'empresa, ubicació respecte al punt de residència, tipus de locomoció. Valoració de les condicions de treball (sou, tipus de feina, companys, empresari, etc.). Grau de participació en els conflictes laborals i opinió general sobre la feina de sindicats $i$ comitès d'empresa.

\section{INSERCIO SOCIAL}

6.1. Evaluació global de les característiques de l'entorn social: a nivell comunitari (en cas de viure en poble o vila), a nivell de barri i de l'entorn més general (en cas de viure en ciutat); opinió sobre veïns i població en general, condicions d'habitabilitat, equipaments, tendes, seguretat personal i habitatges.

6.2. Descripció de l'habitatge: distribució de l'espai, tipus de mobiliari, criteris de decoració, símbols, jerarquies funcionals, utilització de l'espai. Tipus de tenença: propietat o lloguer (especificar valor).

6.3. Opinió general sobre el veïnat, valoració de les experiències personals. Classificació emica dels tipus de veïn que hom considera adequats per a relacions de reciprocitat $\mathrm{i}$ contraprestacions que es desenvolupen amb els propis veïns.

6.4. Grau de participació a les associacions de veïns i d'altres institucions del barri i/o comunitat.

6.5. Llocs on se solucionen els diferents tipus de necessitats en relací a serveis (barri o poble, vila, ciutat, etc.): compra d'aliments $\mathrm{i}$ articles de neteja, roba, electrodomèstics, mobles, objectes de decoració, regals, articles $i$ serveis mèdics de tot tipus, serveis culturals $i$ ensenyament $i$ diversions (cinema, teatre, discoteques. Motius i frequèència en el desplaçament a d'altres ciutats o pobles.

\section{IDENTITAT CULTURAL}

7.1. Sentiment de pertenença. Veure fins a quin punt hom se sent membre del grup ètnic o nacional d'origen propi o del dels pares (p. ex. andalús), o bé membre del poble o comunitat de naixement (p. ex. de Ronda), o bé espanyol com a negació i/o auto-afirmació davant el fenomen català, o bé ha generat una identitat nova de tipus localista desenvolupant una identitat catalana funcional, compatible amb una identitat sentimental arrelada als seus orígens ètnics $\mathrm{i}$ culturals. 
7.2. Quins són els vincles reals amb el poble i la regió originària? Quines són les espectatives reals de tornar-hi? Es viu l'emigració com un exili? ¿Quines són les causes reals per no tornar-hi?: els fills i/o néts «catalans»?, les propietats $\mathrm{i}$ els altres lligams econòmics $\mathrm{i}$ socials que s'han anat fent amb els anys? Potser un cert desarrelament respecte al lloc d'origen...?

7.3. El conflicte d'identitats i la guerra simbòlica: exhibició emblemàtica: banderes, imatges , vestit, música, actes festius, dietètica, vida social, folklore.

7.4. Estudi sobre les transformacions conscients o inconscients en els hàbits quotidians dels immigrants: canvis en el calendari ritual $\mathrm{i}$ festiu, canvis alimentaris en el vestit, en el sistema de creences, en l'aspecte lingüístic.

7.5. Valoració dels aspectes culturals, lingüístics i institucionals diferencials de Catalunya: actitud ideològica $\mathrm{i}$ pràctica. Fer referència als estereotips relatius al indigenes.

ANNEX n. ${ }^{\circ} 2$

CARTA DE PARENTIU: MODEL - FITXA

1/ MODEL DE FULLA DE REGISTRE DEL MATERIAL GENEALOGIC

Nom d'ego:

Data de recollida de la informació:

\begin{tabular}{|l|l|l|l|l|l|l|}
\hline $\begin{array}{c}\text { N. } \\
\text { Ordre }\end{array}$ & $\begin{array}{l}\text { Nom } i \\
\text { Cognoms }\end{array}$ & $\begin{array}{c}\text { Relació } \\
\text { amb ego }\end{array}$ & edat & ofici & $\begin{array}{l}\text { Lloc } \\
\text { Naixem. }\end{array}$ & $\begin{array}{l}\text { Lloc } \\
\text { Resid. }\end{array}$ \\
\hline & & & & & & \\
\hline & & & & & & \\
\hline & & & & & & \\
\hline & & & & & & \\
\hline & & & & & & \\
\hline & & & & & & \\
\hline
\end{tabular}

2) SIGNES CONVENCIONALS EMPRATS EN ELS DIAGRAMES DE PARENTIU

$\triangle$ Home $\bigcirc$ Dona
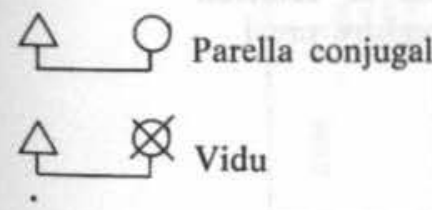

- - - Vincle indeterminat $\diamond$ Sexe indeterminat o desconegut

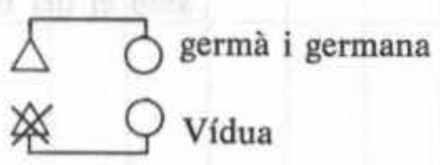

Lligam adoptiu 


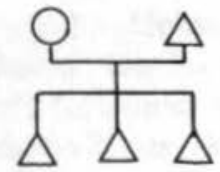

Parella casada amb tres fills

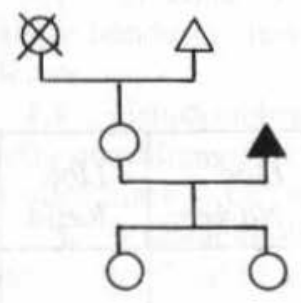

\section{MODEL D'UNITAT DOMESTICA}

El nucli domèstic es delimita sempre per un cercle o «stemma"

El triangle fosc representa ego

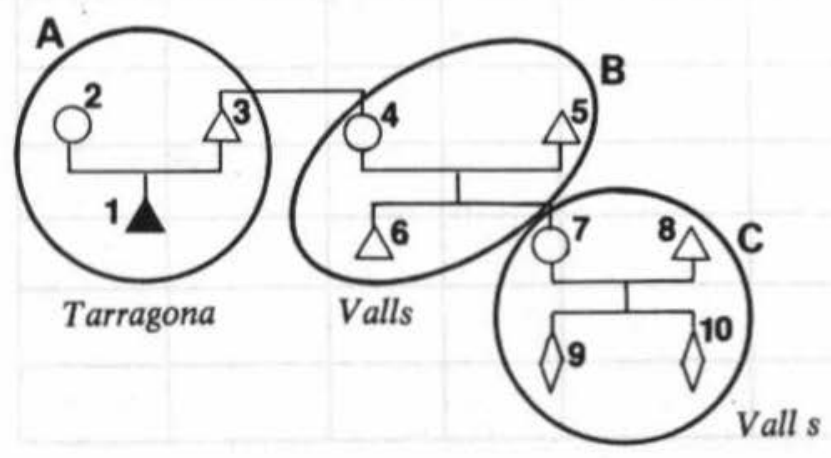

CARTA DE PARENTIU REDUYDA

- Es representen tres grups domèstics (A, B i C) indicant el seu lloc de residència

- Cada membre de la carta té un número d'ordre que ha de coincidir amb el del full de registre previ 


\section{XARXES SOCIALS I FAMILIARS: MODEL - FITXA}

\section{Nom de l'informant:}

\begin{tabular}{|c|c|c|c|c|c|c|c|c|c|c|c|c|c|}
\hline $\begin{array}{l}\text { Núm. } \\
\text { ordre }\end{array}$ & NOM & $\begin{array}{l}\text { A } \\
\text { Nivell } \\
\text { socio } \\
\text { econò } \\
\text { mic }\end{array}$ & $\begin{array}{l}\text { B } \\
\text { Ĺloc } \\
\text { d'origen }\end{array}$ & $\begin{array}{l}\text { C } \\
\text { Anys re- } \\
\text { sidencia } \\
\text { Catalunya }\end{array}$ & $\begin{array}{l}\text { D } \\
\text { Professió }\end{array}$ & $\begin{array}{l}\text { E } \\
\text { Lloc } \\
\text { residèn } \\
\text { cia }\end{array}$ & $\begin{array}{l}\text { Parla } \\
\text { catala? }\end{array}$ & Ambit & $\begin{array}{l}\text { H } \\
\text { Tipus } \\
\text { de relą } \\
\text { ció }\end{array}$ & $\begin{array}{l}\text { I } \\
\text { Inten- } \\
\text { sitat }\end{array}$ & Motiu & $\stackrel{\mathrm{K}}{\text { Signe }}^{\mathrm{K}}$ & $\begin{array}{l}\text { ACTIVITATS CONCRETES } \\
\text { QUE ES REALITZEN }\end{array}$ \\
\hline & & & & & & & \pm 1 & 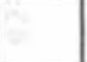 & & $=$ & & & \\
\hline & & & & & & & & & & & & & \\
\hline & & & & & & & & & & & & & \\
\hline & & & & & & & & & & & & & \\
\hline & & & & & & & & & & & & & \\
\hline & 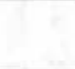 & & & & & & & & & & 8 & & 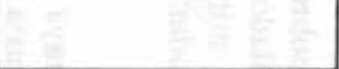 \\
\hline & & & & & & & & & & & $=$ & & \\
\hline & & & & & & & & & & & & & 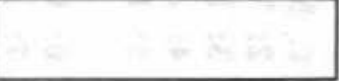 \\
\hline
\end{tabular}


A: 1: Molt pobre/en atur

2: Treballadors

3: Nivell mitjà

4: Acomodat

5: Ric

B: 6: Catalunya

7: Andalusia

8: Extremadura

9: Galícia

10: Castella

11: País Basc

12: Aragó

13: Múrcia

14: València

15: Altres

C: 16: 1-5 anys

17: $6-10$ anys

18: $11-20$ anys

19: més de 20 anys

D: 20: Peonatge

21: Oficial

22: Encarregat

23: Directiu

E: 24: Mateix barri/poble

25: Mateixa comarca

26: Catalunya

27: Fora Catalunya

F: 28: Sí

29: No
G: 30: Familiar

31: Professional (treball, estudis)

32: Paisanatge

33: Veinatge

34: Associació

35: Amistat informa

H: 36: Tertúlies o colles

37: Visites mútues

38: Trobades casuals

39: Relació epistolar o telefonica

40: Reunions formals

41: Vida ritual (casaments, enterraments, festes, etc...)

42: Treball quotidià

I: 43: Molt intenses

44: Freqüents

45: Molt espaiades

46: Circumstancials

J: 47: Per afinitat personal o afecte

48: Per afinitat ideològica

49: Per pressions del grup domèstic

50: Per interessos econòmics

51: Per contacte frequient (laboral...)

52: Per cap motiu especial

K: 53: Relació positiva o d'amistat

54: Relació negativa o d'enemistat

55: Relació neutra

\section{ANNEX n. $0^{\circ} 4$}

\section{GUIA DE CAMP PER L'ESTUDI D'ASSOCIACIONS}

\section{DADES GENERALS}

1.1. Denominació de l'entitat.

1.2. Localització.

1.3. Descripció de les instaHlacions.

1.4. Nombre d'associats i perfil d'aquests: edat, origen, anys dins l'associació, estatus professional $\mathrm{i}$ altres aspectes.

1.5. Anys d'existència de l'associació i etapes significatives per les quals ha passat.

1.6. Eventuals canvis en la denominació i/o en els estatuts.

1.7. Finançament.

\section{FINALITATS}

2.1. Anàlisi dels objectius estatutaris.

2.2. Programa específic de l'actual equip rector i, en el seu cas, referències a les línies o programes de juntes directives anteriors.

2.3. Valoració sobre l'evolució de la quantitat i el tipus d'associats.

2.4. Perfil del soci ideal al qual s'intenten adreçar les activitats $\mathrm{i} / \mathrm{o}$ que agradaria captar com a soci.

2.5. Criteris ideològics $i / 0$ confessionals no explícits que caracteritzen els socis o els directius de l'entitat.

2.6. Anàlisi i valoració de la congruència entre els objectius explícits i les activitats que es realitzen.

\section{ESTRUCTURA}

3.1. Dades personals dels directius: aprofondir el màxim possible.

3.2. Xarxa social dels directius dins la mateixa directiva i en relació al conjunt dels associats: anys, causes i relacions prèvies que vàren motivar la incorporació del directiu a l'associació i, després, a la directiva. 
3.3. Organigrama de l'associació: Junta Directiva, Comissions, Assemblea, etc.

3.4. Nivell de participació dels socis i valoració per part dels directius d'aquesta participació.

3.5. Enquesta entre els associats en relació a l'existència o no de canals de participació.

3.6. Perfil i opinions respecte a juntes directives anteriors.

3.7. Instàncies que organitzen les diferents activitats: grau d'autonomia de les comissions respecte a la Junta Directiva (cercar valoracions).

3.8. Relacions amb altres entitats o Federació d'entitats.

\section{DINAMICA}

4.1. Anàlisi de les activitats de l'Associació $\mathrm{i}$ de les opinions que en tenen els socis i directius. Tractar de fer una comparança amb les activitats d'etapes anteriors.

4.2. Relació amb altres entitats, be sigui de forma oficial, be mitjançant l'activitat d'associats que pertanyen a més d'una entitat.

4.3. Projecció pública de l'entitat: participació en moviments socials o mobilitzacions ciutadanes; adopcí de possicions públiques davant determinats problemes.

4.4. Enquesta d'opinió en relació a les activitats que es pensen dur a terme en un futur immediat o respecte a aquelles activitats desitjades per determinats sectors de l'entitat: tractar de cercar les possibles divergències d'opinió sobre aquest tema.

\section{PUBLICACIONS}

5.1. Publicacions periòdiques de l'entitat: any d'origen, freqüència de la publicació, nombre de pàgines, aspectes formals de l'edició.

5.2. Publicacions no periòdiques: nombre, data, pàgines, motiu de l'edició, altres aspectes formals.

5.3. Caracterització dels responsables de les edicions i la seva vinculació amb la junta directiva de l'entitat. Grau de llibertat o de dependència dels editors respecte als organs directius de l'entitat.

5.4. Grau d'estabilitat o professionalitat dels responsables de les edicions.
5.5. Grau de participació dels socis en les publicacions: articles, collaboracions, cartes al director, etc.

5.6. Projecció social i pública de les diferents publicacions.

\section{ASPECTES LINGUISTICS I CULTURALS}

6.1. Llengua emprada habitualment per a cada activitat.

6.2. Actitud davant les persones que no utilitzen la llengua habitual.

6.3. Llegua emprada per a les actes $\mathrm{i}$ les convocatòries als socis.

6.4. Problemes sorgits amb motiu de qüestions de tipus lingüístic o cultural entre els responsables, socis o participants. Especificar les circumstàncies $\mathrm{i}$ el major nombre de detalls.

6.5. Dimensió simbòlica dels actes i rituals collectius de l'associació: contingut ètnic o cultural.

6.6. Estat d'opinió dels associats i/o directius respecte a la qüestió de la normalització de la llengua i la cultura catalanes. 


\section{ENQUESTA SOBRE IMMIGRACIO, INSERCIO SOCIAL I ACTITUDS} ETNIQUES

Barri o comunitat:

Edad: ............. Sexe: Estat civil:

Lloc de naixement:

Anys de residència a Catalunya:

Data de sortida del poble d'origen:

Ha estat en altres autonomies o països abans d'arribar a Catalunya?

Origen dels pares:

Origen del cònyuge:

Origens dels companys de treball:

Origen dels amics més pròxims:

1. Opcions polítiques que prefereix vostè: *

2. Com es defineix en l'àmbit religiós?:

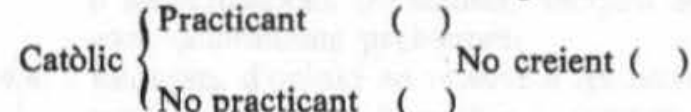

3. Està d'acord amb el feminisme?: Si ( )

4. Nivell d'escolarització: Primària incompleta ( )

$\begin{array}{ll}\text { Primària completa } & (\text { ) } \\ \text { Ensenyament mitjà } & (\text { ) } \\ \text { Ensenyament superior } & (\text { ) }\end{array}$

5. Quina és la seva opció sobre:

SI NO NS/NC

$\begin{array}{ll}\text { OTAN } & (\text { ) } \\ \text { Avortament } & (\text { ) } \\ \text { Divorci } & (\text { ) } \\ \text { Relacions prematrimonials } & (\text { ) } \\ \text { Autonomies } & (\text { ) } \\ \text { Matrimoni } & (\text { ) } \\ \quad \text { - Catolic } & (\text { Civil }\end{array}$

$($ )

() (.)

( ) ( )

( ) ( )
6. A quin collegi porta els nens?

$\begin{array}{lll}\text { Català } & (\text { ) / No català } & (\text { ) } \\ \text { Estatal } & (\text { ) / No estatal } & (\text { ) } \\ & \text { - Religiós } & (\text { ) } \\ \text { Dins del barri } & (\text { ) / Foglar del barri } & (\text { ) }\end{array}$

7. Llegeix revistes, diaris, comics o d'altres publicacions?

$$
\text { S1 ( ) }
$$

Freqüència:

$$
\text { SI ( ) NO ( ) NS/NC ( ) }
$$

9. Què hauria preferit, un tercer canal en Català () ?

$$
\text { Castellà ( )? }
$$

10. Ajuda el marit o d'altres homes de la família en la feina de casa?

$\begin{array}{ll}\text { Fer el llit } & (\text { ) } \\ \text { Parar la taula } & (\text { ) } \\ \text { Netejar els plats } & (\text { ) } \\ \text { Rentar la roba } & (\text { ) } \\ \text { Canviar els infants } & (\text { ) } \\ \text { Netejar la casa } & (\text { ) } \\ \text { Reparacions domèstiques } & (\text { ) }\end{array}$

11. $\mathbf{L i}$ agrada el flamenc?

$$
\text { SI ( ) NO ( ) Indiferent ( ) }
$$

12. Quins cantants catalans coneix?:

13. Escolta normalment emissions de ràdio en català?: S1 ( ) NO ( )

14. Quina opinio li mereix que els homes vagin usualment al bar?:

$$
\text { Favorable ( ) Desfavorable ( ) }
$$

15. Quina opinió li mereix que les dones vagin usualment al bar?

$$
\text { Favorable ( ) Desfavorable ( ) }
$$

16. On sol relacionar-se principalment amb els seus veïns o coneguts del barri?:
A la porta del coHegi
( )
A l'escala
A l'autobús
A la plaça
( )
En una casa
Al carrer
( )
Al bar
A la compra

Pertany a alguna associacio?

Quina?:

\section{SI ( )}

18. Hi participa o hi ha participat activament? 
19. Motius pels quals es desplaça al centre de la ciutat o a la capital de la comarca:

$\begin{array}{llll}\text { Estudis } & (\text { ) } & \text { Laboral } & (\text { ) } \\ \text { Compres } & (\text { ) } & \text { Visites } & (\text { ) } \\ \text { Diversions } & (\text { ) } & \text { Sanitat } & (\text { ) } \\ \text { Altres } & \text { ( ) } & & \end{array}$

20. Quints mitjans de transport utilitza?:

$\begin{array}{llll}\text { Vehicle propi } & (\text { ) } & \text { Autobús } & \text { ( ) } \\ \text { Vehicle d'un company } & (\text { ) } & \text { A peu } & \text { ( ) } \\ \text { Altres } & (\text { ) } & & \text { ( ) }\end{array}$

21. Amb quina freqüència va vostè al centre de la ciutat o a la capital de la comarca?:

$\begin{array}{lll}\text { Diàriament } & (\text { ) } & \text { Semanalment } \\ \text { Cada } 2 \text { o } 3 \text { dies } & (\text { ) } & \text { Amb menys frequència ( ) } \\ \text { Mai } & (\text { ) } & \end{array}$

Mai

( )

22. Ocasions en què va al poble o a la ciutat d'origen:

$\begin{array}{llll}\text { Vacances } & (\text { ) } & \text { Festes } & (\text { ) } \\ \text { Celebracions } & (\text { ) } & \text { Interessos familiars } & (\text { ) } \\ \text { D'altres } & (\text { ) } & \text { Mai } & \text { ( ) }\end{array}$

23. Indicar la jerarquia de les festes numerant de l'1 fins al 3:

$\begin{array}{llll}\text { Sant Jordi } & (\text { ) } & 11 \text { de Setembre } & (\text { ) } \\ \text { Cap d'Any } & (\text { ) } & \text { Carnestoltes } & (\text { ) } \\ \text { Sant Joan } & (\text { ) } & \text { Nadal } & (\text { ) } \\ \text { Setmana Santa } & (\text { ) } & \text { \%iesta del Rocion } & (\text { ) } \\ \text { «Nochebuena» } & (\text { ) } & \text { Festa major del barri o } & \\ \text { Dia de la Mare } & (\text { ) } & \text { comunitat } & (\text { ) } \\ \text { Sant Esteve } & (\text { ) } & \text { Festes del poble o } & \\ \text { 1er. de Maig } & (\text { ciutat d'origen } & \text { ( ) }\end{array}$

24. Com li sembla que són els:
Catalans:
Andalusos:
Gitanos:

25. Quins símbols considera més representatius de Catalunya i del país d'origen? (Prendre com a exemple el cas del País Basc: Ikurriña, Llengua basca, pelotaris, vestit regional, Verge d'Arànzazu, Aberri Eguna, Chistularis...)

Catalunya:

País d'origen:

26. Què és per a vostè: Catalunya ( ) País d'origen ( )
27. I Espanya, què és?:
(2) Una regió

(3) Un poble

(1) Una nació

(2) Un estat

28. Parla vostè el català?:
( ) SEMPRE
( ) A casa
( ) Al treball
( ) On estudia
( ) Amb els amics
( ) A VEGADES
( ) A casa
( ) Al treball
( ) On estudia

( ) MAI

29.* D'ón és, vostè?

30.* Què és, vostè?:

31. Què sent, vostè?:

32. Ha tingut problemes amb els catalans? (En cas afirmatiu, especificar-ne el tipus):
NO ( )

SI ( )

33. I amb la gent d'altres llocs? (En cas afirmatiu, especificar-ne el tipus):

34. Considera que està bé que s'ensenyi el català a l'escola?:

$$
\text { SI ( ) NO ( ) NS/NC ( ) }
$$

35. Creu que ha d'ésser obligatori?:

$$
\text { SI ( ) NO ( ) NS/NC ( }
$$

36. Li agrada a vostè viure al barri o comunitat actual?:

$$
\text { SI ( ) NO ( ) NS/NC ( }
$$

37. Quin és el lloc on més li agradaria viure?:

38. Li agrada viure a Catalunya?:

$$
\text { SI ( ) NO ( }
$$

39. Quins tipus de menjar fa?:

Català ( ) Del lloc d'origen ( ) Mixt ( )

40. Utilitza símbols com ara banderes penjades als balcons o adhesius als cotxes?:

$$
\text { SI ( ) NO ( ) }
$$

41. En cas afirmatiu, indicar si els símbols utilitzats són:

Catalans ( ) Del país d'origen ( ) Espanyols ( )

42. Li sembla que pot resultar bé el matrimoni entre...

\section{(1) Una nació}




$\begin{array}{lll}\text { Gent de religió diferent } & \text { ( ) } & \text { NO } \\ \text { Gent de raça diferent } & (\text { ) } & (1) \\ \text { Gent de classe social diferent } & (\text { ) } & (1) \\ \text { Gent de regió diferent } & (\text { ) } & (1) \\ \text { Gent de cultura diferent } & (\text { ) } & (1) \\ \text { Gent d'idioma diferent } & (\text { ) } & (\text { ) }\end{array}$

Gent d'idioma diferent

43. Escollir entre les 10 possibilitats, les tres coses amb què un més s'identifica, numerant al marge amb els números 1,2 i 3 , segons sigui l'ordre de preferència:

\section{Habitant d'un lloc}

Membre d'un pais

Membre d'una central sindical

Membre d'un grup familiar

Membre d'una associació

Integrant d'un estat

Membre d'un grup d'edat

\section{Part d'un grup professional}

Integrant o simpatitzant d'un grup politic

Membre d'un grup religiós

(P.E.: el barri on visc ara, el poble on vaig néixer...) (P.E.: català, andalús, gallec...)

(P.E.: CC.OO., U.G.T., ,..) (P.E.: pare, mare, marit, ...)

(P.E.: Associacions de veïns, Centre Regional...) (P.E.: l'Espanyol)

(P.E.: jove, adult, jubilat, ...)

(P.E.: obrer, professor, aturat...)

(P.E.: socialistes, comunistes...)

(P.E.: catòlic, protestant...)

48. Posseeix vehicle: SI ( ) NO ( ) Categoria: Moto

( )

Cotxe petit ( ')

Cotxe gran ( )

Furgoneta 0

camió

49. Antiguitat del vehicle, en anys:

50. Electrodomèstics:

$\begin{array}{llll}\text { Rentadora } & \text { ( ) } & \text { Calefacció central } & \text { ( ) } \\ \text { Frigorífic } & \text { ( ) } & \text { Telèfon } & \text { ( ) } \\ \text { Calentador } & \text { ( ) } & \text { Televisió } & \text { ( ) } \\ \text { Vídeo } & \text { ( ) } & \text { Equip de so } & \text { ( ) } \\ \text { Estufa } & \text { ( ) } & \text { Rentaplats } & \text { ( ) }\end{array}$

51. Indiqui, en tot cas, el treball de cada membre de la família i, si pot ser, els ingressos setmanals de cadascú (pregunta discrecional que es pot efectuar només si es dóna el clima de confiança adient amb l'enquestat).

\begin{tabular}{|l|l|l|l|l|l|l|l|l|}
\hline & Pare & Mare & Fill I & Fill II & Fill III & Avia & Avi & Altres \\
\hline $\begin{array}{l}\text { Ingressos } \\
\text { per atur }\end{array}$ & & & & & & & & \\
\hline $\begin{array}{l}\text { Jubilací } \\
\text { o pensió }\end{array}$ & & & & & & & & \\
\hline $\begin{array}{l}\text { Ocupacio } \\
\text { fixa }\end{array}$ & & & & & & & & \\
\hline $\begin{array}{l}\text { Ocupació } \\
\text { eventual }\end{array}$ & & & & & & & & \\
\hline Autònom & & & & & & & & \\
\hline
\end{tabular}

- En cas que no s'aconsegueixi saber les quantitats que cobra cada membre del grup domèstic, ocupeu les caselles corresponents amb una creu, per a poder avaluar quins individus cobren $\mathrm{i}$ per quin concepte. 
52. Ordenar de l'1 fins al 12 els aliments següents, segons el seu nivell de consum:

$\begin{array}{llllll}\text { Fruites ( ) Verdures ( ) Porc i derivats ( ) Alcohol ( ) } \\ \text { Carn ( ) Llet } & \text { ( ) Llegums } & \text { ( ) Dolços } & \text { ( ) } \\ \text { Ous ( ) } \mathrm{Pa} & \text { ( ) Peix } & \text { ( ) Conserves ( ) }\end{array}$

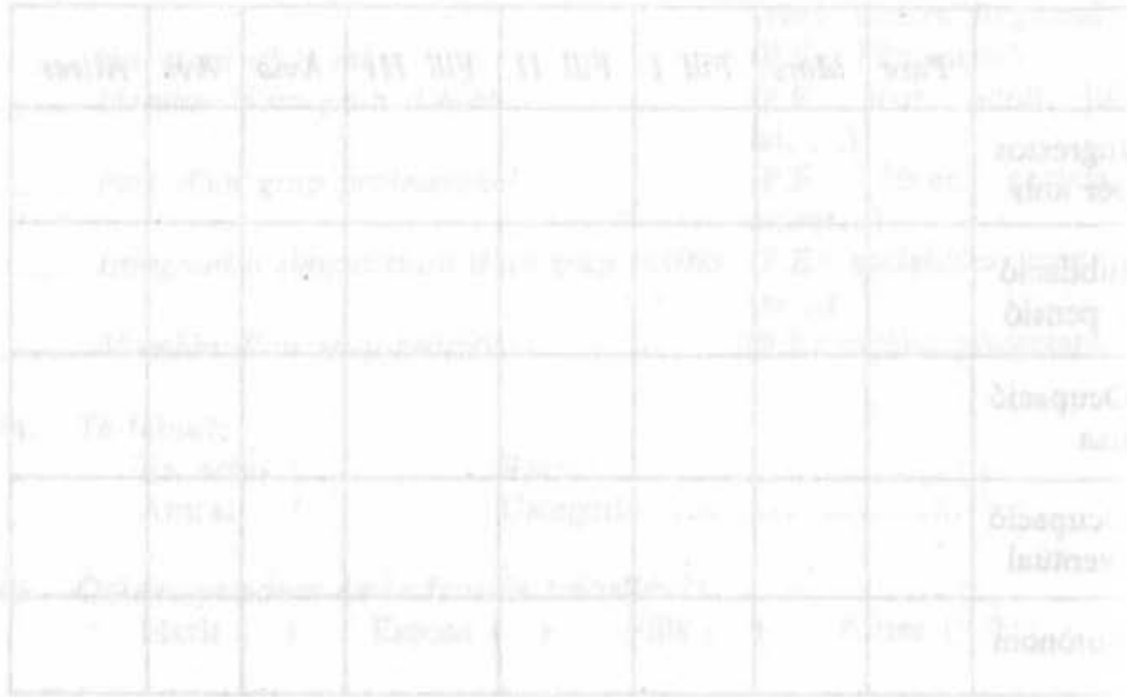

